\title{
ROULEAUX FORMATION OF WHITE BLOOD CELLS AND PLATELETS IN LEUKEMIA
}

\author{
FORMAÇÃO DE ROULEAUX DE GLÓBULOS BRANCOS E PLAQUETAS EM \\ LEUCEMIA
}

\author{
Hafeez ULLAH ${ }^{1}$; Khalid NAEEM²; Munir AKHTAR ${ }^{2}$; Fayyaz HUSSAIN² ${ }^{2}$ Mukhtar AHMAD ${ }^{3}$ \\ 1. Biohotonics Research laboratory, Department of Physics, The Islamia University of Bahawalpur, Bahawalpur, Pakistan; 2. Laser and \\ Optronics Laboratory, Department of Physics, Bahauddin Zakariya University, Unive Bosan Road, Multan, Pakistan; 3. Department of \\ Physics, COMSATS Institute of Information Technology, Lahore, Pakistan.
}

\begin{abstract}
The objective of this study was to measure the effects of glucose and salt level on white blood cells, red blood cells and platelets (PLTs) in the blood of a leukemic patient by using a white light microscope. Different concentrations of glucose and salt in the range of $0 \mathrm{mM}$ to $500 \mathrm{mM}$ were admixed in the blood sample to prepare blood smear. We revealed that shape of erythrocytes, leukocytes and platelets changes and form aggregates. Increasing concentrations of glucose cause to increases aggregation process of white blood cells, red blood cells and platelets. And the increasing concentration of sodium chloride causes to increase rouleaux formation and aggregation of platelets but dehydration due to increased sodium chloride concentration causes to break the aggregation of white blood cells. Comparison of CBC reports of these samples with and without analytes shows that total leukocyte count (TLC) decreases gradually towards normal ranges of leukocytes which is favorable in the treatment of leukemia but at the same time decreasing level of hemoglobin $\mathrm{HGB}$, mean corpuscular hemoglobin $(\mathrm{MCH})$, mean corpuscular hemoglobin concentration (MCHC) and increasing level of red blood cell (RBCs) causes to reduce oxygen supply which is in favor of cancer growth and anemia. This work provides us the base for translation this in vitro study towards the in vivo case of blood microvasculature as a non-invasive methodology.
\end{abstract}

KEYWORDS: White light microscopy. Complete blood count (CBC). Total leukocyte count (TLC). Red blood cell (RBC). White blood cell (WBC). Mean corpuscular hemoglobin (MCH). Mean corpuscular hemoglobin concentration (MCHC).

\section{INTRODUCTION}

Blood is a connective fluid tissue which constitutes about $7 \%$ of our total body weight. It is composed of $45 \%$ of blood cells and $55 \%$ plasma. In living animals, like the human body, blood transport salts, minerals, oxygen, carbon dioxide and ingredients of foods to all parts of the body (JANJUA et al., 2016). A disease in which cells violates normal rules of cell division and continue an uncontrolled growth is called cancer. The spreading of cancerous cells to other parts of the body is called metastasis and if cancerous cells form a clump it is called tumor (HEJMADI, 2009). Leukemia is a non-solid tumor and causes by the abnormal production of WBCs (LAM, 2003). Cancer of leukocytes arises by the mutation in the hematopoietic stem cell. Malignant cells replace and turn off the normal marrow elements, causing anemia, thrombocytopenia, and a deficiency of normally functioning leukocytes. The leukemic cells infiltrate other organs, destroying normal tissue.

Leukemia is caused by abnormal production of white blood cells. Vitamin $\mathrm{C}$ and glucose have the same chemical structure (AFKHAMI-ARDEKANI; SHOJAODDINY-
ARDEKANI, 2007) so when we eat sugar it directly fills the place of vitamin $\mathrm{C}$ in white blood cell and as a result, the active quantity of vitamin C in white blood cell decreases. As sugar is empty calories so it does not help the white blood cells to destroy pathogens (JANJUA et al., 2016). High consumption of sugar suppresses the immune system causes to decrease the phagocytic capacity of neutrophils. Thus, weaken the immune system. According to the scientist Otto Warburg (ANNIBALDI; WIDMANN, 2010) increased levels of sugar cause to increase the production of cancer cells. Tumor cells consume more glucose than normal cells. Tumor cells convert glucose into lactic acid even in the normal supply of oxygen. Tumor cells produce and release many cytokines that increase the accumulation of leukocytes (PRANDONI et al., 2005). As we know that glucose is a form of carbohydrates and is a compound of carbon, oxygen, and hydrogen. Its concentration is controlled by two hormone insulin \& glucagon to keep the normal concentration of glucose in the blood. Any disruption in these hormones leads to hypoglycemia or hyperglycemia which is known as diabetes. All tumor cells have the ability to activate clotting process thus causes the accumulation of different cells like red blood 
cells (RBCs), platelets (PLTs) \& and white blood cells (WBCs)(De Cicco, 2004).

Salt is one of the important gradients of diet to maintain homeostasis in the body. The normal value of $\mathrm{NaCl}$ is $135-145 \mathrm{mM} / \mathrm{L}$. The concentration of sodium chloride affects the blood pressure. Hypernatremia causes high blood pressure. Due to the nucleus and sensitive membrane effect of salt is clear in white blood cells. Increased level of sodium in the blood causes dehydration (ADROGUÉ; MADIAS, 2000) and increase the production of immune cells that cause the autoimmune diseases i.e. they destroy healthy cells (WU et al., 2013, KLEINEWIETFELD et al., 2013). Dysfunction of kidneys, drugs, and excess of water intake causes hyponatremia. In cancer, hyponatremia is more dangerous than hypernatremia (JANJUA et al., 2016). Tumor cells have a higher concentration of sodium inside them than a healthy one.

Accumulation of sodium in blood vessels results in high blood pressure that causes many problems like cardiovascular, renal dysfunction, heart strokes, and stiffness of arteries. Platelet reactivity increases due to the accumulation of sodium, so high intake of sodium chloride results in clumping of platelets and causes high blood pressure.

Different techniques and instruments have been used to observe the effects of two analytes (glucose and Table salt) on blood cells including photoacoustic spectroscopy, mid-infrared spectroscopy, optical coherence tomography, microscopy, computed tomography, optical diffuse reflectance, and light polarimetry etc (JANJUA et al., 2016). The objective of this work was to measure the effects of glucose and salt level on white blood cells, red blood cells and platelets (PLTs) in the blood of a leukemic patient by using a white light microscope.

\section{MATERIAL AND METHODS}

We have used white light digital microscopy (Optika, Italy) and dark field microscopy with CCD camera and have recorded the $2 \mathrm{D}$ images in transmission mode. In light microscopy, intense beam of light is used to make sample visible, objective lens magnify the cells up to many times to analyze cells bodies.

Sample set 1: (Effect of glucose $\left(\mathrm{C}_{6} \mathrm{H}_{12} \mathrm{O}_{6}\right)$ on cells in cancerous blood)
ULLAH, H. et al.

Our sample set 1 consists of six different concentrations i.e. $0 \mathrm{mM}, 100 \mathrm{mM}, 200 \mathrm{mM}, 300$ $\mathrm{mM}, 400 \mathrm{mM}$ and $500 \mathrm{mM}$ of glucose $\left(\mathrm{C}_{6} \mathrm{H}_{12} \mathrm{O}_{6}\right)$ in cancerous blood i.e. leukemia. The corresponding concentrations of glucose were weighed with Sartorius digital balance (least count $0.0001 \mathrm{~g}$ ). Each concentration was prepared in $2 \mathrm{ml}$ blood of leukemia patient with blood group $A+v e$ and aforementioned concentrations of glucose were admixed gently to prepare blood smear of each concentration. The smear of each concentration was examined under a microscope with the objective of $100 \mathrm{X}$ and images were saved with the help of CCD camera.

\section{Sample set 2 (Effects of Salt [NaCl] on cancerous blood)}

Our sample set 2 was prepared with the same protocol as sample set 1 except the analyte was replaced with salt $(\mathrm{NaCl})$ having same concentrations. Here, $0 \mathrm{mM}$ means there is no extra salt is added i.e. inherent salt is present. A centrifuge machine for five minutes at $800 \mathrm{rpm}$ was used to prepare platelet-rich plasma (PRP). The prepared smears were covered with coverslips and examined one by one under the microscope at $40 \mathrm{X}$ in dark field to analyze the effect of sodium chloride on platelets. The blood was drawn after signing a written consent by the donor for the purpose of experimentations.

\section{RESULTS}

\section{For Glucose analyte}

2-D images of each concentration in whole blood of leukemia of WBCs and PLTs under glucose analyte are shown in Figures 1 and 2 respectively. Table 1 gives $\mathrm{CBC}$ reports of glucose containing samples.

\section{For Salt analyte}

2-D images of each concentration in whole blood of leukemia of WBCs and PLTs under salt analyte are shown in Figures 3 and 4 respectively. Table 2 gives $\mathrm{CBC}$ reports of $\mathrm{NaCl}$ containing samples. 


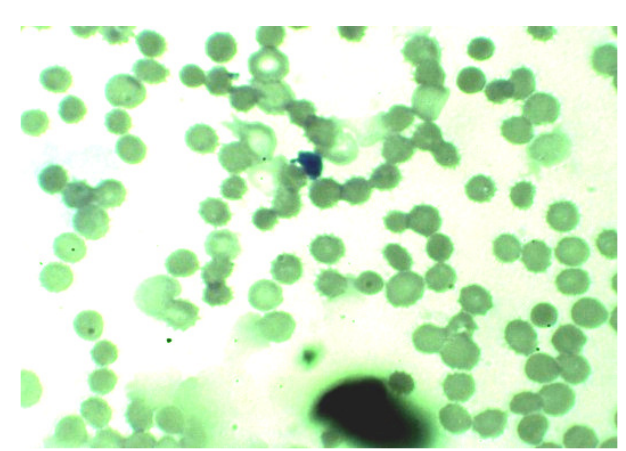

(a)

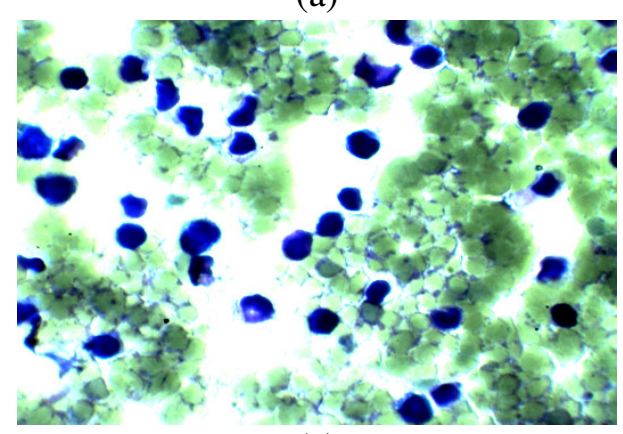

(c)

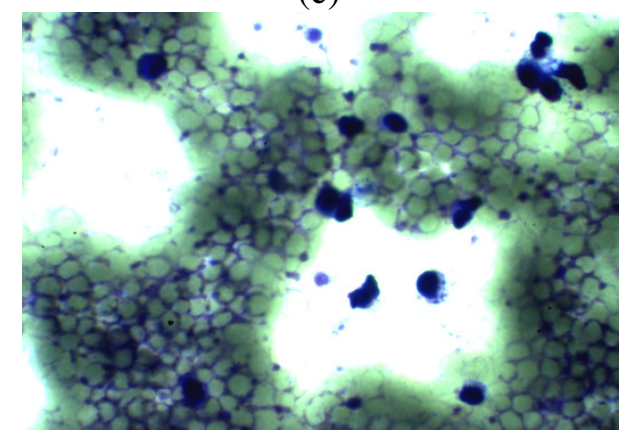

(e)

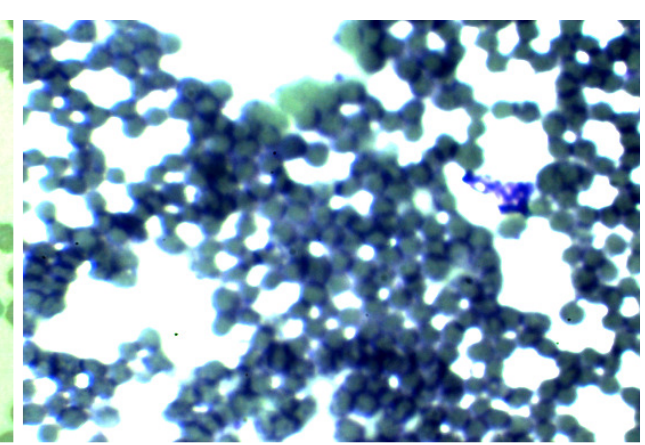

(b)

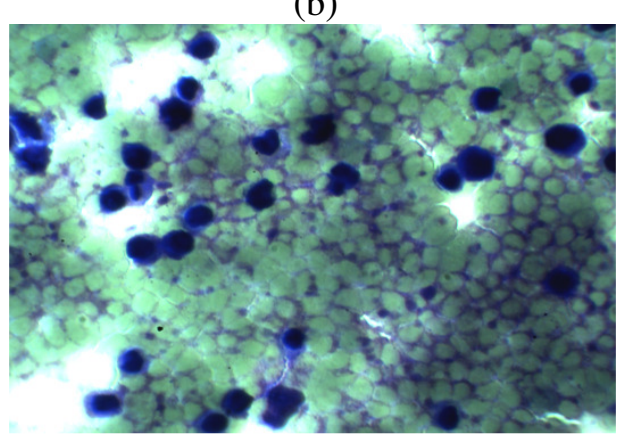

(d)

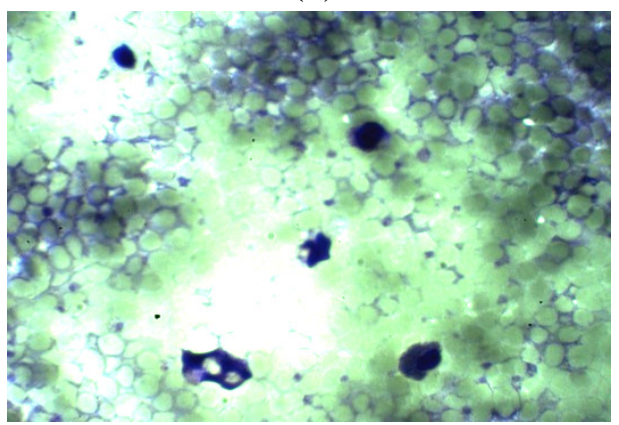

(f)

Figure 1: 2D images of leukocytes and erythrocytes in whole blood of 40 years old leukemic patient obtained with light microscope in transmission mode of glucose concentrations of (a) $0 \mathrm{mM}$, (b) $100 \mathrm{mM}$, (c) $200 \mathrm{mM}$, (d) $300 \mathrm{mM}$, (e) $400 \mathrm{mM}$ and (f) $500 \mathrm{mM}$. 


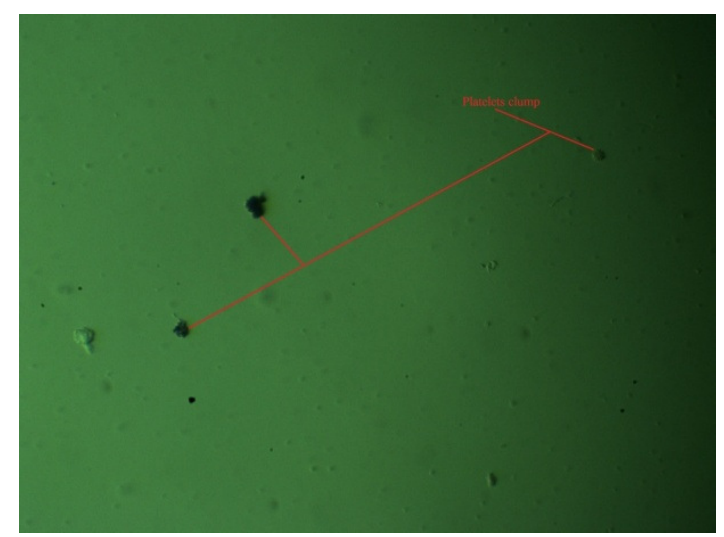

(a)

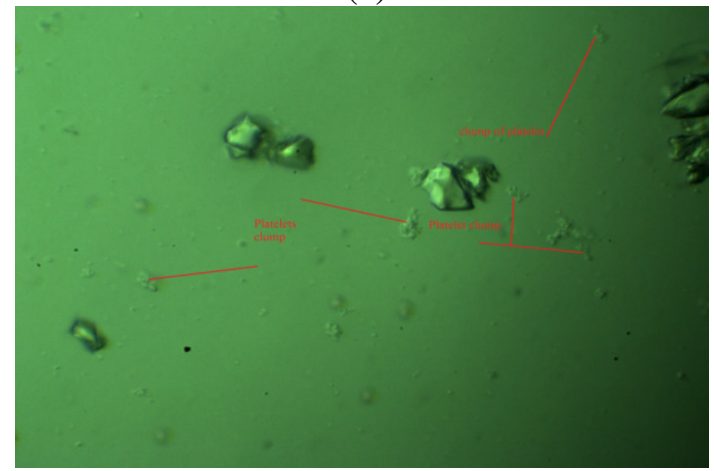

(c)

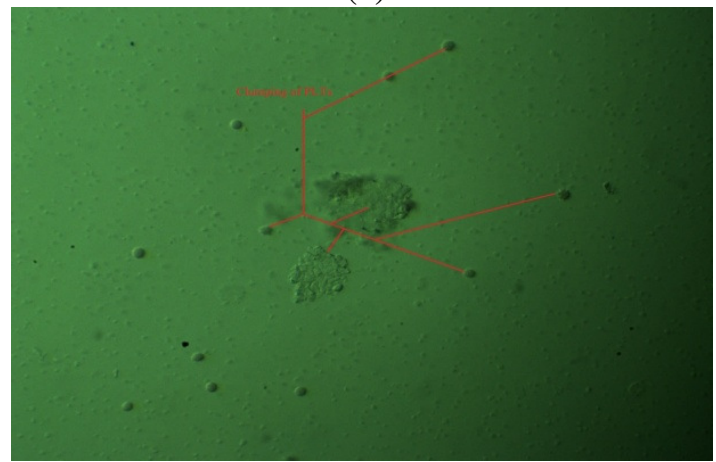

(e)

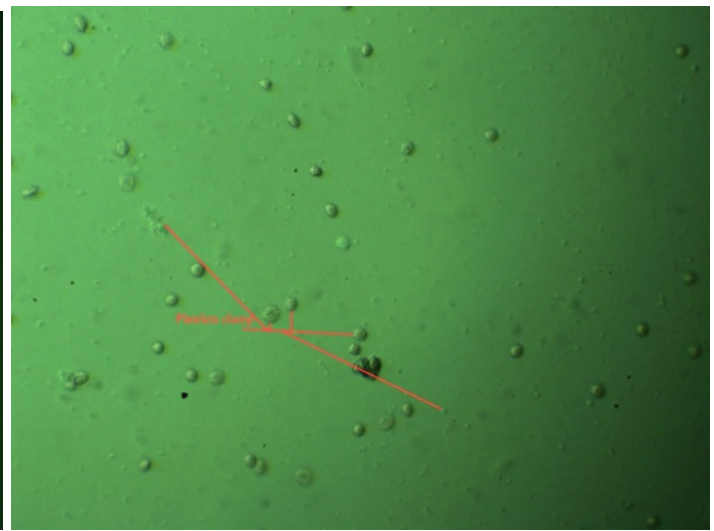

(b)

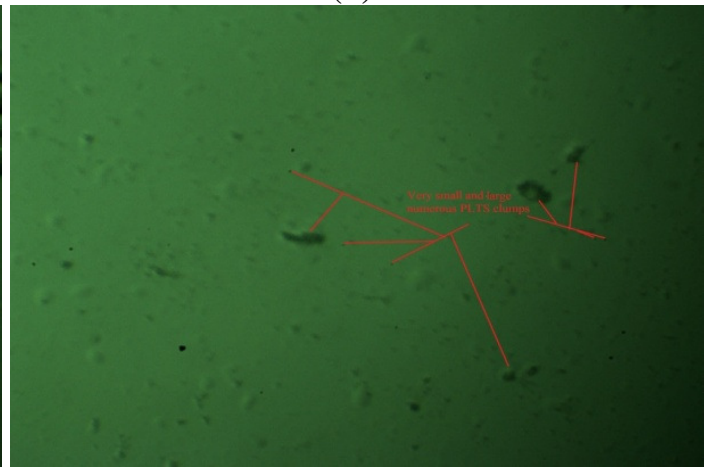

(d)

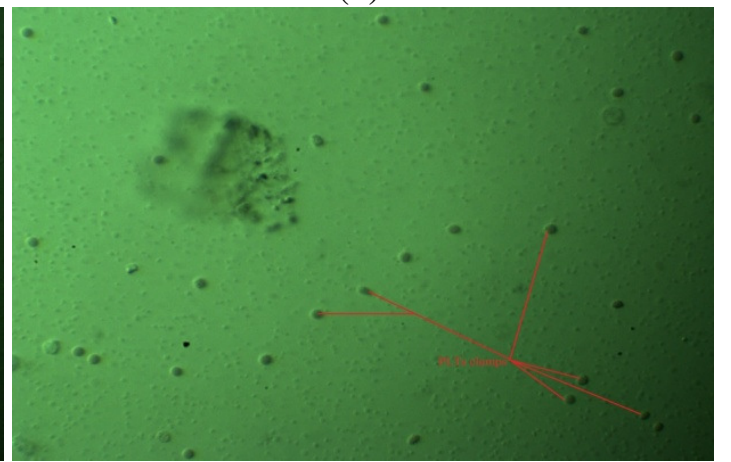

(f)

Figure 2: $2 \mathrm{D}$ images of PRP ( platelet-rich plasma) of leukemic patient with 40X magnification in transmission mode for glucose concentrations (a) $0 \mathrm{mM}$, (b) $100 \mathrm{mM}$, (c) $200 \mathrm{mM}$, (d) $300 \mathrm{mM}$, (e) $400 \mathrm{mM}$, (f) $500 \mathrm{mM}$ 


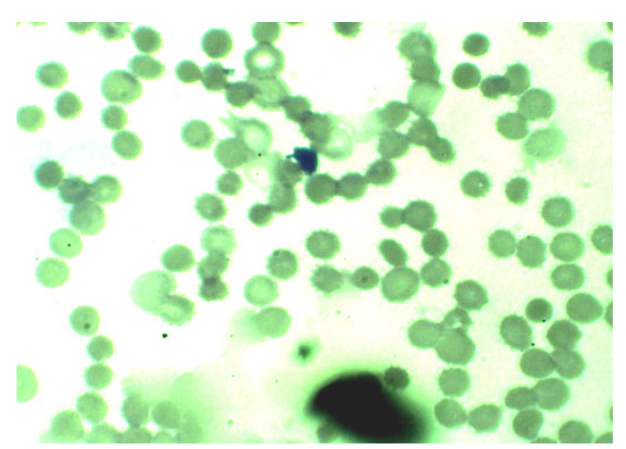

(a)

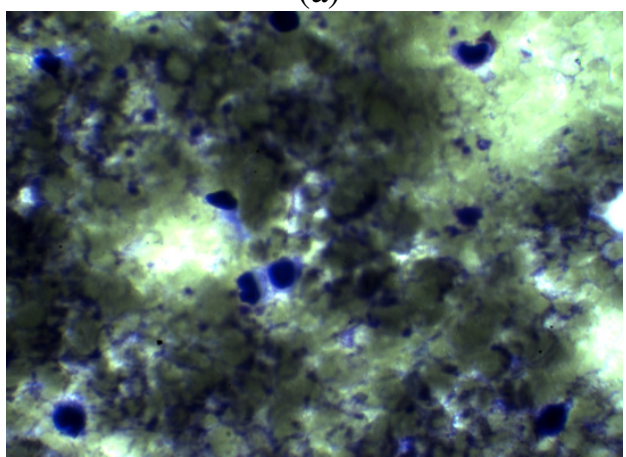

(c)

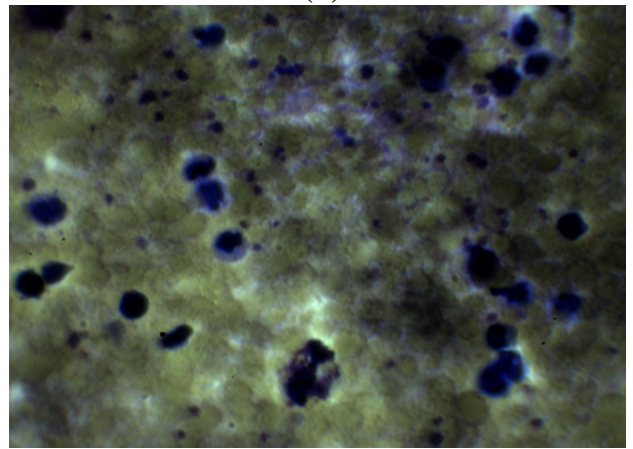

(e)

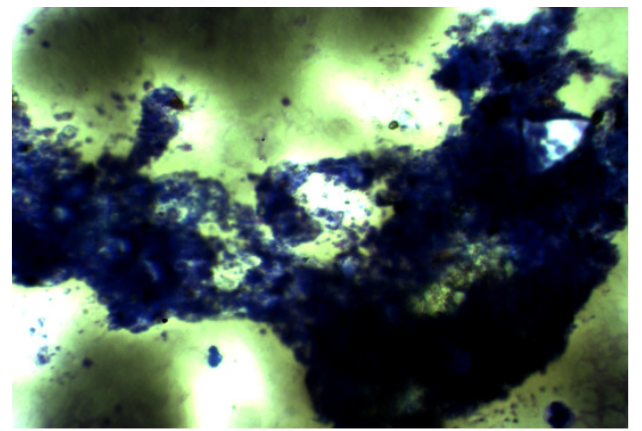

(b)

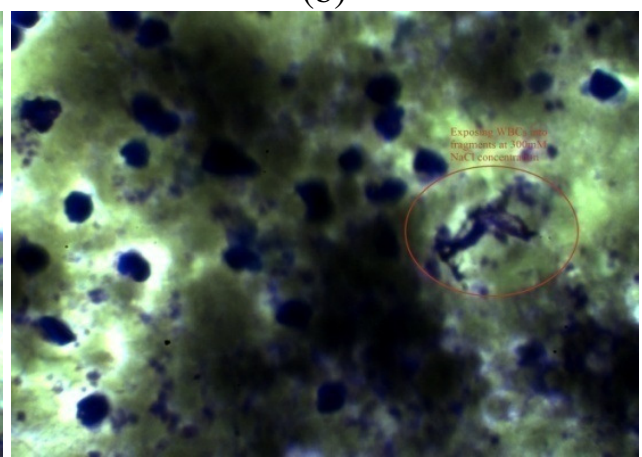

(d)

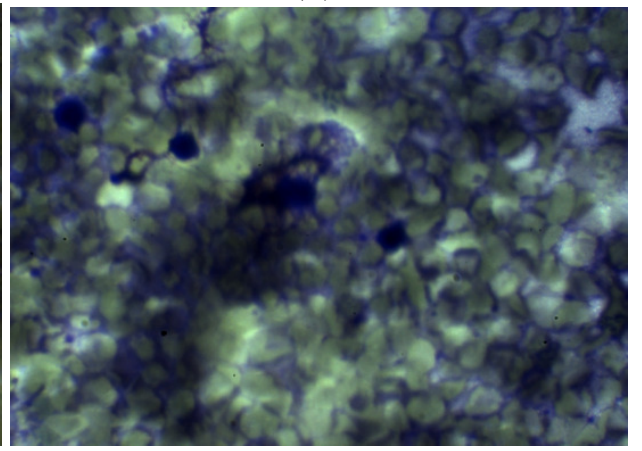

(f)

Figure 3: 2D images of leukemia patient with light microscope 100X magnification in transmission mode for $\mathrm{NaCl}$ concentrations (a) $0 \mathrm{mM}$, (b) $100 \mathrm{mM}$, (c) $200 \mathrm{mM}$, (d) $300 \mathrm{mM}$, (e) $400 \mathrm{mM}$ and (f) $500 \mathrm{mM}$. 


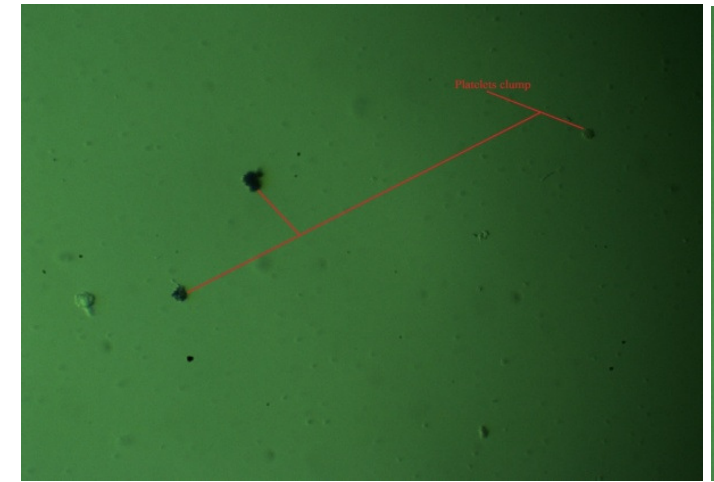

(a)

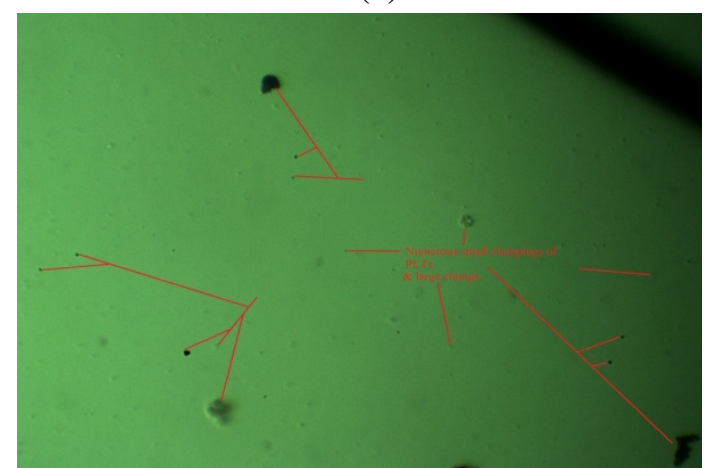

(c)

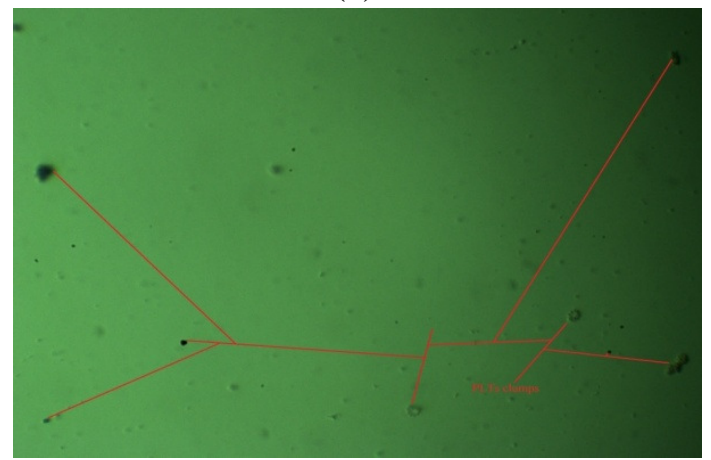

(e)

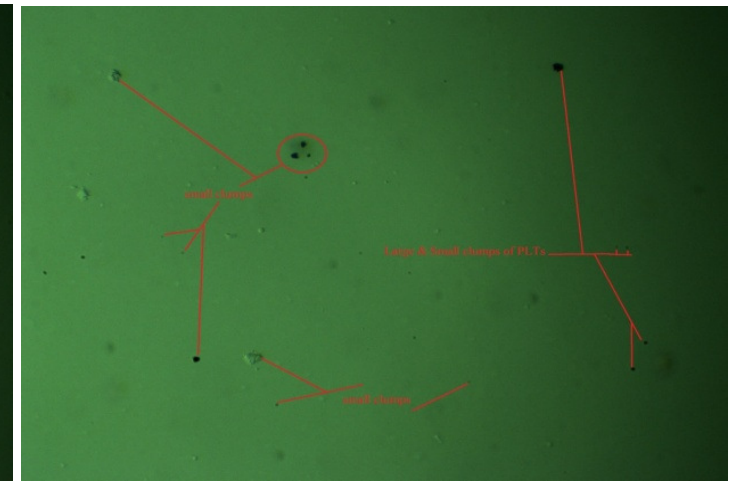

(b)

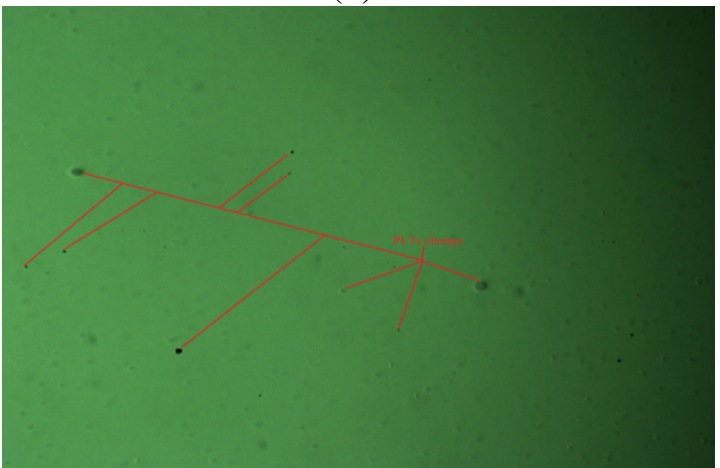

(d)

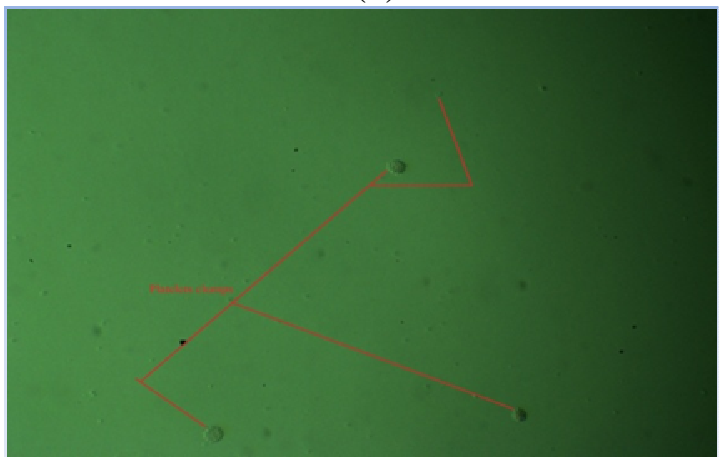

(f)

Figure 4: 2D micrographs of platelets of leukemia patient after addition of sodium chloride with light mode 40X under transmission mode with concentrations (a) $0 \mathrm{mM}$, (b) $100 \mathrm{mM}$, (c) $200 \mathrm{mM}$, (d) 300 $\mathrm{mM}$, (e) $400 \mathrm{mM}$ and $500 \mathrm{mM}$. 
Table 1: CBC reports of glucose-containing samples

\begin{tabular}{|c|c|c|c|c|c|c|c|c|c|c|c|c|c|}
\hline \multirow[t]{2}{*}{$\begin{array}{l}\text { Sr. } \\
\text { No. }\end{array}$} & \multirow[t]{2}{*}{$\begin{array}{l}\text { Conc. } \\
\mathrm{mM}\end{array}$} & \multicolumn{4}{|c|}{$\begin{array}{c}\text { WBC } \\
\times 10^{3} / \mu \mathrm{L}\end{array}$} & \multicolumn{4}{|c|}{$\begin{array}{c}\text { RBC } \\
\times 10^{6} / \mu \mathrm{L}\end{array}$} & \multicolumn{4}{|c|}{$\begin{array}{c}\text { PLT } \\
\times 10^{3} / \mu \mathrm{L}\end{array}$} \\
\hline & & $\mathrm{W}_{1}$ & $\mathrm{~W}_{2}$ & DW & $\%$ & $\mathrm{R}_{1}$ & $\mathrm{R}_{2}$ & DR & $\%$ & $P_{1}$ & $\mathrm{P}_{2}$ & DP & $\%$ \\
\hline 1 & 100 & 131 & 97.7 & -33.3 & 25.4 & 4.33 & 4.40 & +0.07 & 1.62 & 965 & 968 & +03 & 0.003 \\
\hline 2 & 200 & 125 & 84.2 & -40.8 & 32.6 & 3.39 & 3.59 & +0.20 & 5.90 & 171 & 265 & +94 & 54.9 \\
\hline 3 & 300 & 11 & 10.1 & -0.9 & 8.1 & 4.62 & 5.02 & +0.40 & 8.65 & 193 & 194 & +01 & 0.005 \\
\hline 4 & 400 & 13.7 & 12.5 & -1.2 & 8.7 & 4.55 & 4.87 & +0.32 & 7.03 & 147 & 103 & -47 & -31.97 \\
\hline 5 & 500 & 91.7 & 66.2 & -25.5 & 27.8 & 4.12 & 4.24 & +0.12 & 2.91 & 1599 & 1501 & -98 & -6.13 \\
\hline \multirow{3}{*}{$\begin{array}{l}\text { Sr. } \\
\text { No }\end{array}$} & \multirow{3}{*}{$\begin{array}{l}\text { Con } \\
\text { c. } \\
\text { mM }\end{array}$} & \multirow{2}{*}{\multicolumn{4}{|c|}{$\begin{array}{c}\mathrm{MCH} \\
\mathrm{Pg}(\text { pico-gram })\end{array}$}} & \multirow{2}{*}{\multicolumn{4}{|c|}{$\begin{array}{l}\mathrm{MCHC} \\
\mathrm{g} / \mathrm{dL}\end{array}$}} & \multirow{2}{*}{\multicolumn{4}{|c|}{$\begin{array}{l}\text { HGB } \\
\mathrm{g} / \mathrm{dL}\end{array}$}} \\
\hline & & & & & & & & & & & & & \\
\hline & & $\begin{array}{c}\mathrm{MC} \\
\mathrm{H}_{1} \\
\end{array}$ & $\begin{array}{c}\mathrm{MC} \\
\mathrm{H}_{2} \\
\end{array}$ & $\begin{array}{c}\text { D.me } \\
\mathrm{h}\end{array}$ & $\%$ & $\begin{array}{c}\mathrm{MCH} \\
\mathrm{C}_{1} \\
\end{array}$ & $\begin{array}{c}\mathrm{MCH} \\
\mathrm{C}_{2} \\
\end{array}$ & $\begin{array}{l}\text { D.MCH } \\
\text { C }\end{array}$ & $\%$ & $\begin{array}{c}\text { HGB } \\
1\end{array}$ & $\begin{array}{c}\mathrm{HGB} \\
2\end{array}$ & $\begin{array}{c}\text { D.HG } \\
\text { B }\end{array}$ & $\%$ \\
\hline 1 & 100 & 30.3 & 28.7 & -1.6 & 5.2 & 34.1 & 28.7 & -5.4 & $\begin{array}{c}15.8 \\
3\end{array}$ & 13.1 & 12.5 & -0.6 & 4.5 \\
\hline 2 & 200 & 30.4 & 30.4 & +00 & 00 & 34.3 & 27.5 & -6.8 & $\begin{array}{c}19.8 \\
2\end{array}$ & 11.9 & 10.9 & -1.0 & 8.4 \\
\hline 3 & 300 & 29.1 & 25.7 & -3.4 & $\begin{array}{c}11.6 \\
8\end{array}$ & 32.6 & 26.3 & -6.3 & 19.3 & 13.5 & 12.9 & -0.6 & 4.4 \\
\hline 4 & 400 & 32.4 & 29.8 & -2.6 & 8.02 & 33.3 & 27.8 & -5.5 & 16.5 & 14.7 & 14.5 & -0.2 & 1.36 \\
\hline 5 & 500 & 29.3 & 25.0 & -4.3 & $\begin{array}{c}14.6 \\
7\end{array}$ & 32.9 & 25.7 & -7.2 & $\begin{array}{c}21.8 \\
8\end{array}$ & 12.0 & 10.6 & -1.4 & $\begin{array}{c}11.6 \\
6\end{array}$ \\
\hline
\end{tabular}

Table 2: CBC reports of $\underline{\mathrm{NaCl}}$ containing samples

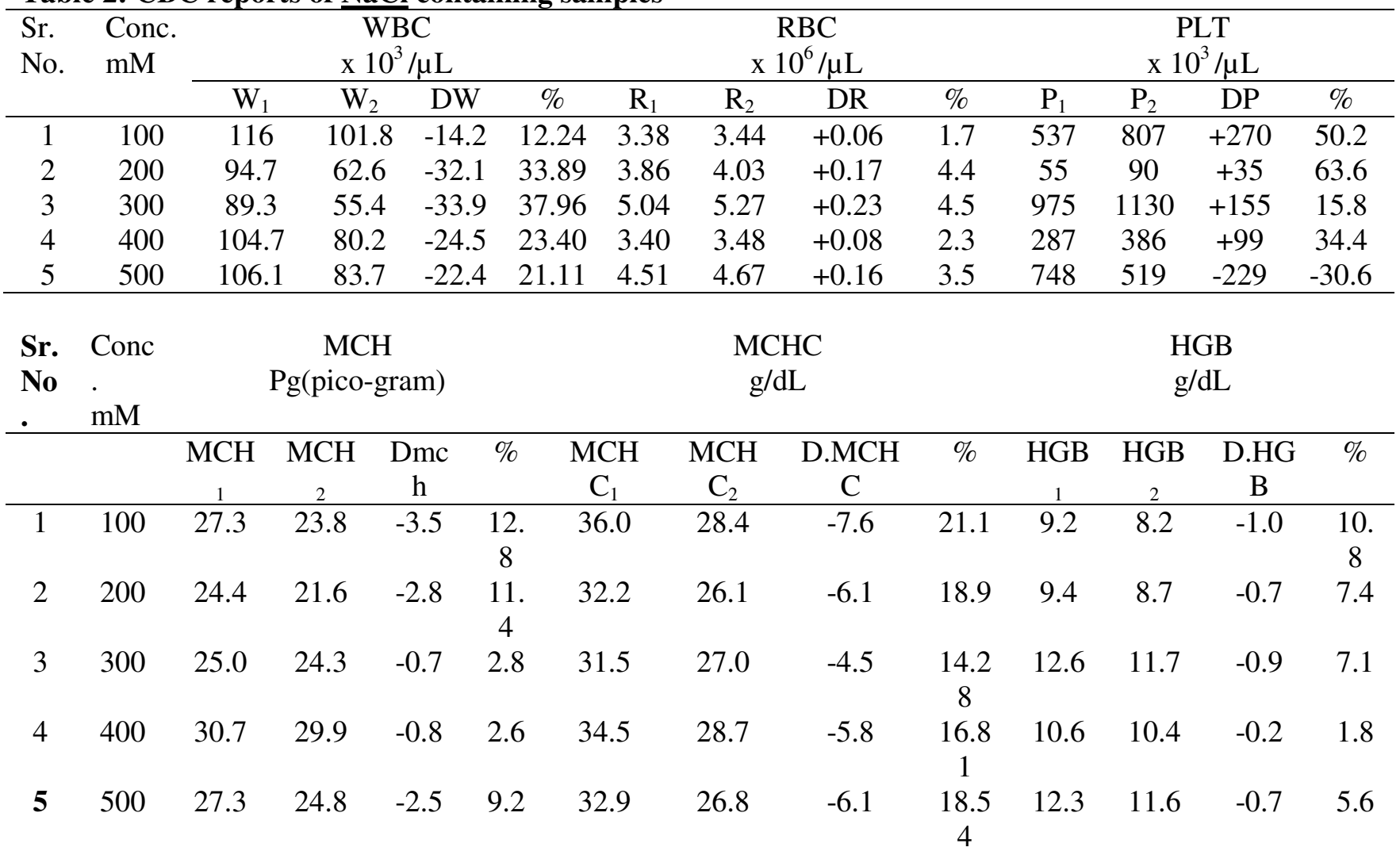

Note: Subscript "1" shows normal count while subscript "2" represents count after mixing analytes. "D" represents the difference. "-ve" sign represents decreasing count and "+ve" represents increasing count. "\%" represents percentage count with respect to normal count. Variations in these parameters based on $\mathrm{CBC}$ reports are plotted in Figures 5 for easy analysis. 


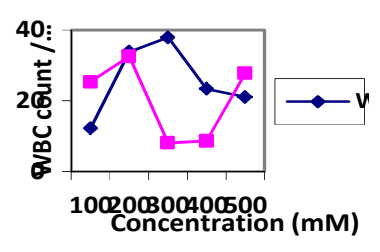

(a)

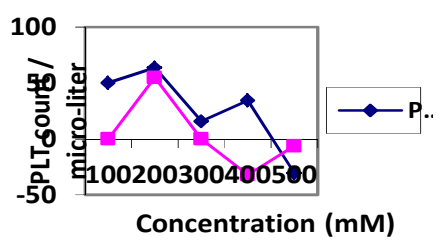

(c)

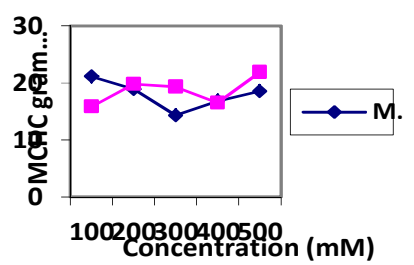

(e)

Figure 5. The effect of $\mathrm{NaCl}$ and glucose on percentage blood components (b)

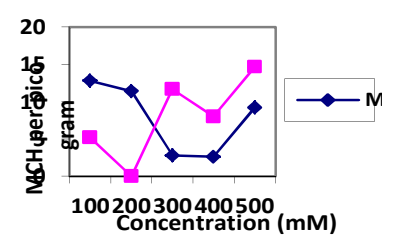

(d)

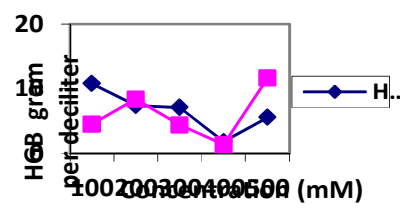

\section{DISCUSSIONS}

Sample with $0 \mathrm{mM}$ sugar shows that there are broken and abnormal WBCs present in the leukemic patient as shown in Figure 1(a). With increasing glucose concentration, white blood cells absorb sugar undergo shape changes i.e. from round to oval shape and start to disintegrate (parts of WBCs spreads all around RBCs) as shown in Figure 1(b, c, d). At a further higher concentration of glucose along with disintegration and shape changes of leukocytes, they start to accumulate and cause to aggregate. At a high intake of glucose accumulation, distortion of leukocytes increases shown in Figure $1(\mathrm{e}, \mathrm{f})$. Leukocytes count increases in hyperglycemia (PANNACCIULLI et al., 2003) and is positively related to plasma glucose level i.e. neutrophils increases but eosinophils decreases (XU et al., 2013).

The concentration of fibrinogen and (FPA) fibrin peptide-A [macromolecules] increases in acute leukemia. Fibrin deposits are also present around tumor cells (RICKLES; EDWARDS, 1983) so stacks of erythrocytes are already present in the leukemic patient as shown in Figure 1(a). As the increasing concentration of glucose increase the tumor growth causes to increase the production of macromolecules which act as a bridge between erythrocytes resulting in the stacking of red blood cells. So with the increase in the molar concentration of glucose, aggregation of red blood cells also increases i.e. rouleaux formation is 
directly linked with glucose concentration as shown in Figure 1(b, c, d, e, f). Hyperglycemia damages the structure of erythrocytes (MAZZANTI et al., 1992, BUYS et al., 2013) and increases the level of MCV (HOSSEINI et al., 2014).

Tumor cells produce and release many cytokines that increase the accumulation of leukocytes and PLTs (PRANDONI et al., 2005). Therefore we see that in blood cancer sample with no sugar clumping of PLTs is already present as shown in Figure 2(a). Increasing glucose concentration causes to increase the aggregation of platelets in leukemia because sugar increases the cancer growth. Increasing glucose concentration causes to increase the level of ADP, fibrinogen, thromboxane $\mathrm{A}_{2}$ collagen and von Willebrand factor VWF in leukemia by malignant WBCs so platelets aggregation increases as shown in Figure 2(b, c, d, $e, f)$.

Hyperglycemia increases the risk of blood cancer (CASTILLO et al., 2012). Leukemia and hyperglycemia both suppress the immune system and increases the risk of infections. A modest level of hyperglycemia in leukemia causes hospital mortality (ALI et al., 2007, ALI et al., 2006), it may also occur during leukemia therapy and may be fatal (WANG et al., 1993, ALI et al., 2006). So it is necessary to control blood glucose level during treatment (PUI et al., 1981, HARRIS et al., 2013).

Leukemic micrograph with no additional salt shows that abnormal white blood cells are already present as shown in Figure 3(a). At low concentration, i.e.at $100 \mathrm{mM}$ of $\mathrm{NaCl}$ an extra large clump of WBCs is formed as shown in Figure 3(b) which is the confirmation that hyponatremia is more dangerous than hypernatremia. At further increasing concentration, we observe that shape of leukocytes changes due to dehydration and accumulation of sodium ions inside them increases and clumping is broken down, parts of white blood cells scattered around RBCs. Increasing quantity of sodium serves as an anticoagulant and bursting agent for WBCs as shown in Figure 3(c, d, e, f). WBCs count is elevated in hypertension (WHITWORTH, 2004, NAKANISHI et al., 2002, SUN et al., 2015).

The surfaces of RBCs are coated with glycocalyx rich in water and anionic glycosaminoglycan. Surface electronegativity creates a potential called zeta potential that is counteracted by plasma captions. $\mathrm{Na}$ ion interacts strongly with the RBC glycocalyx. The high charge density of $\mathrm{Na}$ ion is attracted by the negatively charged glycocalyx surface, $\mathrm{Na}$ ion attracts the polar water molecules to a larger extent. Excessive plasma $\mathrm{Na}$ ion causes to decrease zeta potential to a very small value which causes the aggregation of red blood cells (OBERLEITHNER, 2015). We observe that molar concentration of sodium chloride is directly related with rouleaux formation i.e. aggregation of RBCs is increases by depletion model which describe that depletion of surface charge causing the aggregation of red blood cells (WAGNER et al., 2013, BÄUMLER et al., 1999). Since increasing concentration of sodium chloride continuously decrease the negative charge density of erythrocytes, therefore aggregation of red blood cells increases with increasing $\mathrm{NaCl}$ quantity 0 $\mathrm{mM}, 100 \mathrm{mM}, 200 \mathrm{mM}, 300 \mathrm{mM}, 400 \mathrm{mM}, 500$ $\mathrm{mM}$ as shown in Figures 3(a, b, c, d, e, f). We observe that at 400 and $500 \mathrm{mM}$ rouleaux formation is more severe than at lowers one as can be seen in Figure 3(e, f). Hypertension alters erythrocytes structure, reduces oxygen transport, increases blood viscosity and rouleaux formation (CICCO; PIRRELLI, 1999). Hypertension increases RBCs count and reduces MCV (SUN et al., 2015).

Hypernatremia causes high blood pressure. Accumulation of Sodium in platelet increases its reactivity (ADROGUE; MADIAS, 1997, FRASER; ARIEFF, 1997). High salt concentration changes reactivity of platelet cells. Therefore, high intake of salt affects on adrenaline gland that acts on membranes of platelet and causes to aggregate them (LAURENO; KARP, 1997, AYUS et al., 1987). We see that clumping of platelets is already present in blood cancer patient as shown in Figure 4(a). Increasing concentrations of $\mathrm{NaCl}$ i.e. 100, 200, 300,400 , and $500 \mathrm{mM}$ causes to increase platelets aggregation at a higher rate which is the confirmations that $\mathrm{NaCl}$ causes PLTs aggregation as shown in Figure 4(b, c, d, e, f). After leukemia therapy, there is a risk of hypertension ( $\mathrm{CHOW}$ et al., 2007). So, hypertension should be properly controlled during and after therapy.

Figure 5(a) represents the effect of $\mathrm{NaCl}$ and glucose on WBC in blood cancer. Percentage of damaged WBC increases from 100-300 mM concentration of $\mathrm{NaCl}$ and then decreases gradually on further increasing salt concentration. In glucose concentration percentage of dead WBC is minimum at 300 and $400 \mathrm{mM}$ but maximum at $200 \mathrm{mM}$ i.e. $32.6 \%$ leukocytes are destroyed at $200 \mathrm{mM}$. TLC decreases gradually which shows that these analytes destroy leukocytes since it is an in vitro study that's why no leukocytes are added from bone marrow in blood to elevate its level. Figure 5(b) represents the effect of salt and glucose on percentage count of RBC per micro-liter. Erythrocyte count increases in both concentrations. Effect of glucose on percentage erythrocyte count is more prominent than salt. Both 
salt and glucose damaged RBC structure and percentage count increases. At $100 \mathrm{mM}$ effect of salt and glucose is the same. From 100-300mM glucose concentration percentage of RBCs increases more rapidly than salt, at $400-500 \mathrm{mM}$ glucose concentration percentage count decreases.

Figure 5(c) represents the effect of salt and glucose on percentage count of PLTs per microliter. Thrombocytes are increased in both salt and glucose; having maximum values at $200 \mathrm{mM}$ for both. Thrombocytes count increases up to $300 \mathrm{mM}$ but at a concentration above $400 \mathrm{mM}$ in glucose and $500 \mathrm{mM}$ in salt damaged its structure causes to decrease their counts and form aggregates. The decreases at a slow rate towards the normal ranges which is again favorable but the damaged thrombocytes and leukocytes adhere. The aggregation causes to increase the blood viscosity, cardiovascular problems and other complications in a leukemic patient. Figure 5(d) represents the effect of salt and glucose on percentage count of $\mathrm{MCH}$ per picogram. Effect of glucose on $\mathrm{MCH}$ is severe than salt. The decrease of $\mathrm{MCH}$ is maximum at a lower concentration of salt and a higher concentration of glucose.

Figure 5 (e) represents the effect of salt and glucose on percentage count of MCHC gram per deciliter decreases in both samples. It decreases maximum at $100 \mathrm{mM}$ of salt and $500 \mathrm{mM}$ of glucose. Figure 5(f) represents the effect of salt and glucose on percentage count of HGB gram per deciliter decreases. It also decreases maximum at $100 \mathrm{mM}$ of salt and $500 \mathrm{mM}$ of glucose. RBCs count increases that result in increasing rouleaux formation while a decrease of $\mathrm{MCH}, \mathrm{HGB}$, and $\mathrm{MCHC}$ results to reduce the transport of oxygen to speed up cancer cell growth and also increase the risk of anemia.

Salt deactivate WBCs by dehydration and changes their shape but sugar deactivates them by suppressing their phagocytic properties. In the treatment of blood cancer, therapy having the side effects of hypertension and hyperglycemia can cause the patient's death because damaged blood components are adhered to aggregate and increase blood viscosity which leads to cardiovascular complications like a heart attack. Avoiding the things which are rich in sugar and salt and use of fresh fruit juices are favorable in blood cancer treatment.

\section{CONCLUSIONS}

Sugar speeds up cancer growth and enhances the cancer growth production factors like fibrinogen etc. Distortion of WBCs is maximum at low glucose level but on further increasing glucose concentration, it starts decreasing at a slow speed.

The percentage count of WBCs decreases and RBCs increases in glucose concentrations. Accumulation of white blood cells and rouleaux formation increases with increasing concentration of sugar in the blood of leukemia patient.

Aggregation of platelets is already present in the leukemic patient. As sugar causes the increases in cancer growth, so, aggregation of platelets also increases. Large and small clumping of PLTs increases with increasing glucose level causes clotting in arteries which reduce the blood flow results a cardiac disease. Moreover, thrombocytopenia occurs due to the shortage of normal platelets because thrombocytes are damaged above $400 \mathrm{mM}$.

Hyponatremia causes WBCs aggregation while increasing salt concentration in blood (hypernatremia) results in the break off leukocytes clumps and cell structure due to dehydration and percentage count per micro-liter decreases at a different rate.

Due to negative charge surface of RBC, sodium ions accumulates around red blood cells strongly and deplete electrostatic repulsion between erythrocytes which causes strong aggregation of red blood cells and percentage count increases at a different rate.

$\mathrm{NaCl}$ concentration is directly related to the rouleaux formation. Increasing concentration of salt causes aggregation of platelets at a slow rate and clumping of platelets becomes severe above 400 $\mathrm{mM}$ concentrations because PLTs starts damaged at increasing rate. Both diabetes and hypertension in leukemia are fatal because they facilitate rouleaux formation, aggregation of leukocytes and thrombocytes causes to increase the blood viscosity and suppress the immune system.

RESUMO: O objetivo deste estudo foi medir os efeitos da glicose e do nível de sal nos glóbulos brancos, glóbulos vermelhos e plaquetas (PLTs) no sangue de um paciente leucêmico usando um microscópio de luz branca. Foram misturadas diferentes concentrações de glicose e sal na gama de $0 \mathrm{mM}$ a $500 \mathrm{mM}$ na amostra de sangue para preparar esfregaço de sangue. Descrevemos que a forma dos eritrócitos, leucócitos e plaquetas muda e forma agregados. O aumento das concentrações de glicose aumenta o processo de agregação de glóbulos brancos, glóbulos vermelhos e plaquetas. E a 
crescente concentração de cloreto de sódio causa o aumento da formação de rouleaux e a agregação de plaquetas, mas a desidratação devido ao aumento da concentração de cloreto de sódio causa a quebra da agregação de glóbulos brancos. A comparação dos relatórios de CBC dessas amostras com e sem analitos mostra que a contagem total de leucócitos (TLC) diminui gradualmente para os intervalos normais de leucócitos, o que é favorável no tratamento da leucemia, mas ao mesmo tempo diminui o nível de hemoglobina HGB, hemoglobina corpuscular média (MCH ), a concentração média de hemoglobina corpuscular (MCHC) e o aumento do nível de glóbulos vermelhos (RBCs) reduz o suprimento de oxigênio, o que é a favor do crescimento do câncer e da anemia. Este trabalho fornece a base para a tradução deste estudo in vitro para o caso in vivo de microvasculatura de sangue como uma metodologia não-invasiva.

PALAVRAS-CHAVE: Microscopia de luz branca. Hemograma completo (CBC). Contagem total de leucócitos (TLC). Glóbulos vermelhos (RBC). Glóbulos brancos (WBC). Hemoglobina corpuscular média (MCH). Concentração hemoglobina corpuscular média (MCHC).

\section{REFERENCES}

ADROGUE, H.; MADIAS, N. 1997. Aiding fluid prescription for the dysnatremias. Intensive care medicine, v. 23, p. 309-316. https://doi.org/10.1007/s001340050333

ADROGUÉ, H. J.; MADIAS, N. E. 2000. Hypernatremia. New England Journal of Medicine, v. 342, p. 1493-1499. https://doi.org/10.1056/NEJM200005183422006 https://doi.org/10.1056/NEJM200005253422107

AFKHAMI-ARDEKANI, M.; SHOJAODDINY-ARDEKANI, A. 2007. Effect of vitamin C on blood glucose, serum lipids \& serum insulin in type 2 diabetes patients. Indian Journal of Medical Research, v. 126, 471p.

ALI, N. A.; O'BRIEN, J. M.; BLUM, W.; BYRD, J. C.; KLISOVIC, R. B.; MARCUCCI, G.; PHILLIPS, G.; MARSH, C. B.; LEMESHOW, S.; GREVER, M. R. 2007. Hyperglycemia in patients with acute myeloid leukemia is associated with increased hospital mortality. Cancer, v. 110, p. 96-102.

https://doi.org/10.1002/cncr.22777

ALI, N. A.; O'BRIEN, J. M.; BLUM, W.; KLISOVIC, R. B.; MARCUCCI, G.; PHILLIPS, G.; MARSH, C. B.; LEMESHOW, S.; BYRD, J. C.; GREVER, M. R. 2006. Hyperglycemia in Patients with Acute Myeloid Leukemia Is Associated with Increased Hospital Mortality. Blood, v. 108, p. 5515-5515.

ANNIBALDI, A.; WIDMANN, C. 2010. Glucose metabolism in cancer cells. Current Opinion in Clinical Nutrition \& Metabolic Care, v. 13, p. 466-470. https://doi.org/10.1097/MCO.0b013e32833a5577

AYUS, J. C.; KROTHAPALLI, R. K.; ARIEFF, A. I. 1987. Treatment of symptomatic hyponatremia and its relation to brain damage. New England Journal of Medicine, v. 317, p. 1190-1195.

https://doi.org/10.1056/NEJM198711053171905

BÄUMLER, H.; NEU, B.; DONATH, E.; KIESEWETTER, H. 1999. Basic phenomena of red blood cell rouleaux formation. Biorheology, v. 36, p. 439-442.

BUYS, A. V.; VAN ROOY, M.-J.; SOMA, P.; VAN PAPENDORP, D.; LIPINSKI, B.; PRETORIUS, E. 2013. Changes in red blood cell membrane structure in type 2 diabetes: a scanning electron and atomic force microscopy study. Cardiovascular diabetology, v. 12, 1. https://doi.org/10.1186/1475-2840-12-25

CASTILLO, J. J.; MULL, N.; REAGAN, J. L.; NEMR, S.; MITRI, J. 2012. Increased incidence of nonHodgkin lymphoma, leukemia, and myeloma in patients with diabetes mellitus type 2: a meta-analysis of observational studies. Blood, p. 119, p. 4845-4850. https://doi.org/10.1182/blood-2011-06-362830

CHOW, E. J.; PIHOKER, C.; HUNT, K.; WILKINSON, K.; FRIEDMAN, D. L. 2007. Obesity and hypertension among children after treatment for acute lymphoblastic leukemia. Cancer, v. 110, p. 2313-2320. https://doi.org/10.1002/cncr.23050 
CICCO, G.; PIRRELLI, A. 1999. Red blood cell (RBC) deformability, RBC aggregability and tissue oxygenation in hypertension. Clinical hemorheology and microcirculation, v. 21, p. 169-177.

DE CICCO, M. 2004. The prothrombotic state in cancer: pathogenic mechanisms. Critical Reviews in Oncology/Hematology, v. 50, p. 187-196. https://doi.org/10.1016/j.critrevonc.2003.10.003

FRASER, C. L.; ARIEFF, A. I. 1997. Epidemiology, pathophysiology, and management of hyponatremic encephalopathy. The American journal of medicine, v. 102, p. 67-77. https://doi.org/10.1016/S00029343(96)00274-4

HARRIS, D.; BARTS, A.; CONNORS, J.; DAHL, M.; ELLIOTT, T.; KONG, J.; KEANE, T.; THOMPSON, D.; STAFFORD, S.; UR, E. 2013. Glucocorticoid-induced hyperglycemia is prevalent and unpredicTable for patients undergoing cancer therapy: an observational cohort study. Current Oncology, v. 20, p. 532-538. https://doi.org/10.3747/co.20.1499

HEJMADI, M. 2009. Introduction to Cancer Biology, Ventus Publishing.

HOSSEINI, H.; DORGALALEH, A.; TABIBIAN, S.; KASHIRI, M.; MOGHADDAM, E. S.; ALIZADEH, S.; BAMEDI, T.; REYKANDE, S. E.; DORGALALEH, S. 2014. Biochemical Interfering Factors and Blood Cells Indices. Thrita, 3.

JANJUA, H. U.; AKHTAR, M.; HUSSAIN, F. 2016. Effects of sugar, salt and distilled water on white blood cells and platelet cells: A review. Journal of Tumor, v. 4, p. 354-358. https://doi.org/10.17554/j.issn.18196187.2016.04.73

KLEINEWIETFELD, M.; MANZEL, A.; TITZE, J.; KVAKAN, H.; YOSEF, N.; LINKER, R. A.; MULLER, D. N.; HAFLER, D. A. 2013. Sodium chloride drives autoimmune disease by the induction of pathogenic TH17 cells. Nature, v. 496, p. 518-522. https://doi.org/10.1038/nature11868

LAM, M. 2003. Beating cancer with natural Medicine, AuthorHouse.

LAURENO, R.; KARP, B. I. 1997. Myelinolysis after correction of hyponatremia. Annals of Internal Medicine, v. 126, p. 57-62. https://doi.org/10.7326/0003-4819-126-1-199701010-00008

MAZZANTI, L.; FALOIA, E.; RABINI, R. A.; STAFFOLANI, R.; KANTAR, A.; FIORINI, R.; SWOBODA, B.; DE PIRRO, R.; BERTOLI, E. 1992. Diabetes mellitus induces red blood cell plasma membrane alterations possibly affecting the aging process. Clinical biochemistry, v. 25, p. 41-46. https://doi.org/10.1016/00099120(92)80044-H

NAKANISHI, N.; SATO, M.; SHIRAI, K.; SUZUKI, K.; TATARA, K. 2002. White blood cell count as a risk factor for hypertension; a study of Japanese male office workers. Journal of hypertension, v. 20, p. 851-857. https://doi.org/10.1097/00004872-200205000-00018

OBERLEITHNER, H. 2015. Sodium selective erythrocyte glycocalyx and salt sensitivity in man. Pflügers Archiv-European Journal of Physiology, v. 467, p. 1319-1325. https://doi.org/10.1007/s00424-014-1577-0

PANNACCIULLI, N.; GIORGINO, F.; MARTINA, R. A.; RESTA, O.; GIORGINO, R.; PERGOLA, G. 2003. Effect of family history of type 2 diabetes on white blood cell count in adult women. Obesity research, v. 11, p. 1232-1237. https://doi.org/10.1038/oby.2003.169

PRANDONI, P.; FALANGA, A.; PICCIOLI, A. 2005. Cancer and venous thromboembolism. The lancet oncology, v. 6, p. 401-410. https://doi.org/10.1016/S1470-2045(05)70207-2 
PUI, C.-H.; BURGHEN, G. A.; BOWMAN, W. P.; AUR, R. J. 1981. Risk factors for hyperglycemia in children with leukemia receiving L-asparaginase and prednisone. The Journal of pediatrics, v. 99, p. 46-50. https://doi.org/10.1016/S0022-3476(81)80955-9

RICKLES, F. R.; EDWARDS, R. L. 1983. Activation of blood coagulation in cancer: Trousseau's syndrome revisited. Blood, v. 62, p. 14-31.

SUN, Y. T.; GONG, Y.; ZHU, R.; LIU, X.; ZHU, Y.; WANG, Y.; QIU, Q.; QI, L.; LIANG, J. 2015.

Relationship between white blood cells and hypertension in Chinese adults: the Cardiometabolic Risk in Chinese (CRC) study. Clinical and Experimental Hypertension, v. 37, p. 594-598.

https://doi.org/10.3109/10641963.2015.1036058

WAGNER, C.; STEFFEN, P.; SVETINA, S. 2013. Aggregation of red blood cells: from rouleaux to clot formation. Comptes Rendus Physique, v. 14, p. 459-469. https://doi.org/10.1016/j.crhy.2013.04.004

WANG, Y.; CHU, H.; SHU, S.; CHI, C. 1993. Hyperglycemia induced by chemotherapeutic agents used in acute lymphoblastic leukemia: report of three cases. Zhonghua yi xue za zhi= Chinese medical journal; Free China ed, v. 51, p. 457-461.

WHITWORTH, J. A. 2004. Relationship between white blood cell count and incident hypertension. American journal of hypertension, v. 17, 861p. https://doi.org/10.1016/j.amjhyper.2004.05.021

WU, C.; YOSEF, N.; THALHAMER, T.; ZHU, C.; XIAO, S.; KISHI, Y.; REGEV, A.; KUCHROO, V. K. 2013. Induction of pathogenic TH17 cells by inducible salt-sensing kinase SGK1. Nature, v. 496, p. 513-517. https://doi.org/10.1038/nature11984

XU, W.; WU, H.-F.; MA, S.-G.; BAI, F.; HU, W.; JIN, Y.; LIU, H. 2013. Correlation between peripheral white blood cell counts and hyperglycemic emergencies. International journal of medical sciences, v. 10, 758p. https://doi.org/10.7150/ijms.6155 